\title{
DEVELOPING AN INTERACTIVE LEARNING MODEL USING VISUAL BASIC APPLICATIONS WITH ETHNOMATHEMATICAL CONTENTS TO IMPROVE PRIMARY SCHOOL STUDENTS' MATHEMATICAL REASONING
}

\author{
Euis Eti Rohaeti ${ }^{1 *}$, Nelly Fitriani ${ }^{1}$, Fadillah Akbar ${ }^{2}$ \\ ${ }^{1}$ Insititut Keguruan dan Ilmu Pendidikan Siliwangi, Indonesia \\ ${ }^{2}$ SMP Putra Juang, Indonesia
}

\begin{tabular}{l} 
Article Info \\
\hline Article history: \\
Received Aug 4, 2020 \\
Revised Aug 30, 2020 \\
Accepted Sep 29, 2020 \\
\hline
\end{tabular}

\section{Keywords:}

Interactive learning, Visual Basic Application, Ethnomathematical, Primary school, Mathematical reasoning

\begin{abstract}
This study aims to examine the development of an interactive learning model using Visual Basic Application for Microsoft excel with ethnomathematical content on fractions, to improve primary school students' mathematical reasoning abilities. The research method used is development through the stages of conducting preliminary studies and literature, designing interactive learning models, conducting FGDs, producing initial designs of interactive learning models, conducting limited trials in one primary school, making revisions, conducting extensive trials in four primary schools, producing trial in another primary school. The last obtaining a final model and conducting socialisation. The last, it provides a test of mathematical reasoning ability. The research subjects were teachers and students in six primary schools. The research instruments were interviews, validation sheets, documentation, learning observation sheets, questionnaires and mathematical reasoning ability test. The assessment criteria for the developed learning model include syntax, social system, principle of reaction, supports system and instructional impact. The results showed that 1) Development of VBA-assisted and ethnomatematically-loaded interactive learning models go through two major stages, namely product development and validation 2) The Interactive learning model was declared very valid; 3 ) The responses of teachers and students were generally positive; 4) The achievement of students' mathematical reasoning abilities after gave learning with an interactive model using VBA for Microsoft Excel with ethnomathematical contents better than using ordinary learning.
\end{abstract}

Copyright $(2020$ IKIP Siliwangi. All rights reserved.

\section{Corresponding Author:}

Euis Eti Rohaeti,

Departement of Mathematics Education,

Institut Keguruan dan Ilmu Pendidikan Siliwangi,

Jl. Terusan Jenderal Sudirman, Cimahi, West Java 40526, Indonesia.

Email: e2rht@ikipsiliwangi.ac.id

\section{How to Cite:}

Rohaeti, E. E., Fitriani, N., \& Akbar, F. (2020). Developing an interactive learning model using visual basic applications with ethnomathematical contents to improve primary school students' mathematical reasoning. Infinity, 9(2), 275-286. 


\section{INTRODUCTION}

In primary school from first to the sixth grade, students begin to learn mathematics. In this level of education, one of the problematic materials for students is fractions, because, at fractions, students are required to practice their logical reasoning skills and draw conclusions from some given examples.

The reasoning is both a student's inductive and deductive logical thinking process in solving problems (Bernard, 2014, 2015; Nugraha et al., 2015). Mathematical reasoning has a significant role in students' thinking process because if students' reasoning abilities are not developed, mathematics learning will only become material that follows a series of procedures and imitates examples without knowing their meaning (Nugraha et al., 2015).

The Trends International Mathematics and Science Study (TIMSS) survey in 2011 (Mullis et al., 2015), Indonesia ranked 36 out of 40 participating countries, with the lowest reasoning score of 17 points. Based on previous research conducted by Nurkhaeriyyah, Rohaeti, \& Yuliani (2018) show that the average level of mathematical reasoning ability in middle school is still low.

Besides, the results of TIMSS and PISA (Program for International Students Assessment) over the last few years show that the results of student mathematics learning in Indonesia, especially regarding mathematical reasoning, are still low and are below Malaysia and Singapore (Chotimah et al., 2018). Some of these findings indicate that the reasoning ability of students in Indonesia is low.

It is needed to initiate the Learning process that can train students' reasoning skills, especially at fractions in primary schools, one of which is the Interactive Learning Model assisted by VBA for Excel. The interactive learning model emphasises student questions as to its characteristic, in the interactive learning model questions will often appear, and the questions may vary. Meanwhile, Visual Basic Application for Microsoft Excel is a programming language feature that can process data automatically by utilising mathematical functions using Visual Basic code assistance (Chotimah et al., 2018; Fitriani et al., 2018; Rohaeti et al., 2019).

With VBA for Microsoft Excel, we can create interactive learning media that can train students' reasoning skills in a comfortable, interesting, fun and useful way. The media produced is straightforward to reproduce, develop, understand by students, and be used by both teachers and students at school. Besides that the media produced can be made thematic as desired, one of which is by including ethnomathematics elements in it, so that learning will be more meaningful and easily understood by students because it has cultural elements that are very common for students (Barton, 1996; d'Ambrósio, 2006).

\section{METHOD}

The research conducted is developmental research which aims to develop interactive learning on fractions material using VBA for Microsoft Excel. The resulting product is an interactive learning model on primary school fractions with the help of VBA for Microsoft Excel and contains ethnomathematics. The research stages carried out were adopted from the Borg and Gall's development model (Borg \& Gall, 1989), as in Figure 1. 


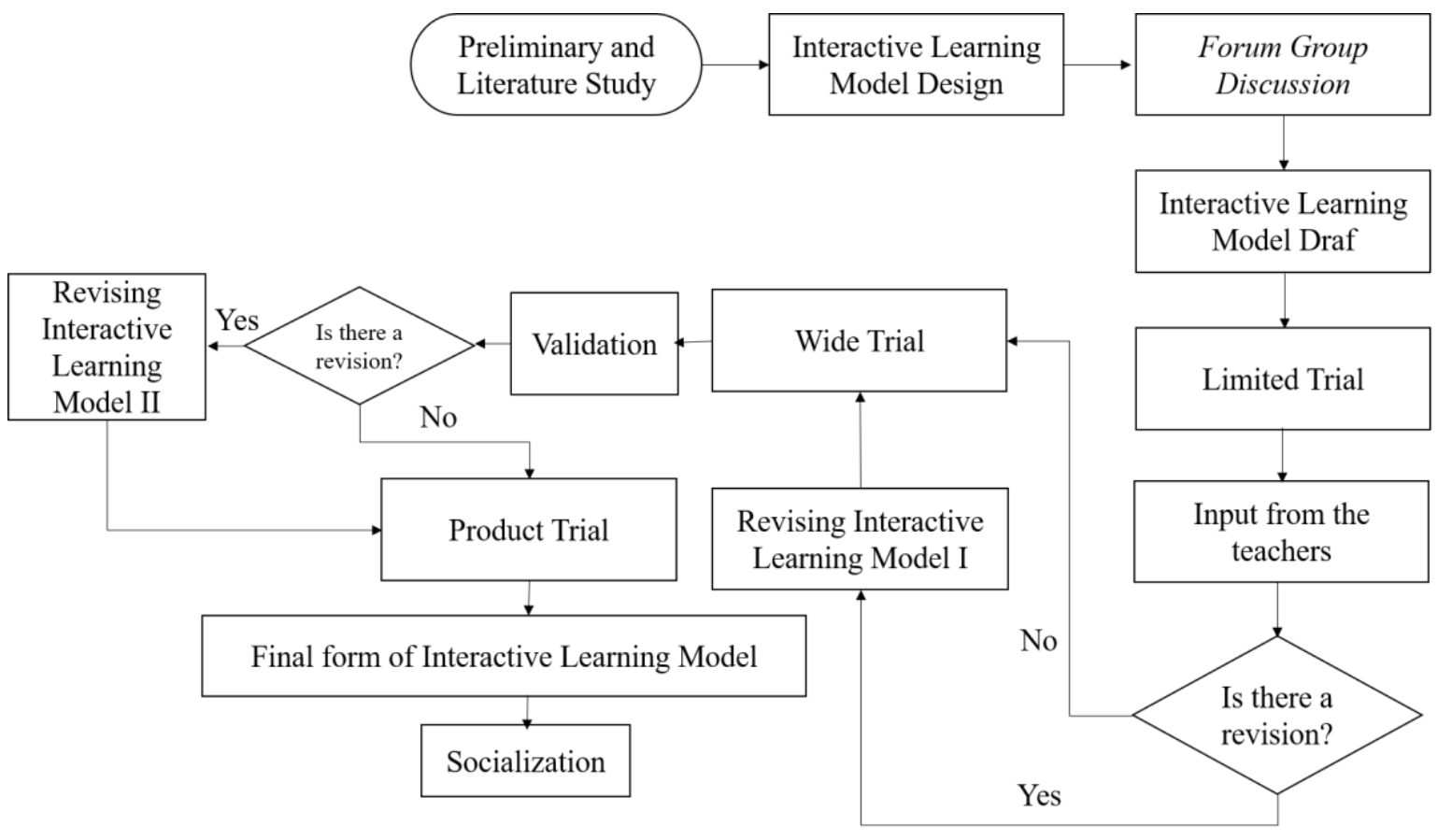

Figure 1. Research flow

Figure 1 shows the stages of compiling an interactive learning model using VBA for Microsoft Excel with ethnomathematics content. In the initial stage, the researcher conducted a preliminary study in the form of a literature study, a school survey and drafting. In the literature study, the researcher conducted a study of the theories relating to the interactive learning model that will be developed. The literature study also examines the characteristics of Upper-Class Students at the primary school, especially in their mathematical reasoning abilities. Also, relevant previous research results are also reviewed. The school survey was conducted to observe the learning of fraction which has been carried out by primary school teachers, and interviews also conducted to these teachers so that it is known what learning deficiencies must be improved.

Based on the result of the literature study and survey, the authors make a draft of an interactive learning model that will be developed. The design of the model was then revised in a Forum Group Discussion (FGD) which was attended by mathematics learning experts, supervisors, media experts and several experienced senior primary school teachers. Limited trials were conducted at one of the public primary schools in Cianjur after the researchers previously compiled an interactive learning model. Based on the findings on a limited trial, the researchers made improvements to the design of the learning model. Henceforth, more extensive trials were carried out at four primary schools in Jakarta, West Java and East Java. The results of the trial are then re-validated for product testing, and a final interactive learning model is produced. In the product test at another primary school in Cianjur, a mathematical reasoning ability test was carried out on students using interactive learning model products compared to those using ordinary learning. Finally, the product was socialised to primary school teachers in West Java.

The research instruments were interviews, validation sheets, documentation, learning observation sheets, tests and questionnaires. The data analysis technique uses descriptive statistics to analyse the scores on the characteristics of the developed interactive learning model, which also takes into account the input from the validator to improve the learning 
model. The assessment criteria for the developed learning model include syntax, social system, the principle of reaction, support system and instructional impact (Joyce \& Weil, 1986) in the form of scores from 1 to 4 . The results were then converted into a criteria table to be converted into quantitative data. The learning model validation criteria can be seen in the following Table 1.

Table 1. Criteria for the validity of the learning model

\begin{tabular}{ccc}
\hline Score & Validity Category & Interpretation \\
\hline $20-24$ & Very valid & Very good to use \\
$16-19$ & Valid & May be used with minor revisions \\
$11-15$ & Quite Valid & May be used with major revisions \\
$6-10$ & Invalid & Should not be used \\
\hline
\end{tabular}

(Adopted from Akbar, 2013)

According to Akbar (2013), the learning model is declared valid if the three elements of the validation have been declared valid. The three elements of validation are validation by experts consisting of three learning expert lecturers, user validation by three elementary school teachers who are experienced teaching, and audience validation by students by giving scores on student response questionnaires. In addition, this learning model is said to be useful for improving mathematical thinking if the product test results show that the mathematical reasoning of students using the developed learning model is better than those using ordinary learning.

\section{RESULTS AND DISCUSSION}

\subsection{Results}

\subsubsection{Development of an interactive learning model}

Development of interactive learning model with VBA for Microsoft Excel with Ethnomathematical contents begins with a preliminary study stage and literature study. From the results of the preliminary study and literature study, an interactive learning model draft was then designed. Focus Group Discussion (FGD) was conducted to get input on the draft model made. The implementation involved four lecturers, five primary teachers and three postgraduate students of mathematics education at IKIP Siliwangi in which there were validation activities for the developed learning model. The input from the FGD for the improvement of the draft design of the interactive learning model is that the delivery of material is more systematic, designed to be more coherent and efficient so that it becomes more practical to use. After the FGD was carried out, necessary revisions were made to the draft of the interactive learning model design so that it was ready to be used in a limited trial at one of the public primary schools in Cianjur. The following images are examples of devices and media used in a limited trial (see Figure 2). 

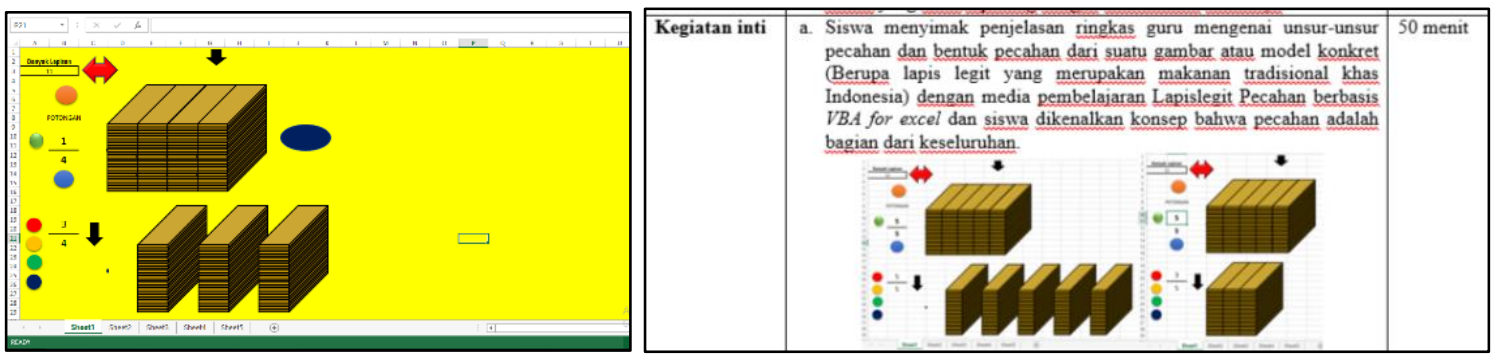

Figure 2. Example of media used in a limited trial

From the results of the limited trial, more input was obtained so that there could be more cultural elements. For this reason, improvements were made by including the layer legit media and Wayang Golek into the learning media used. Based on the revision of the results on the limited trial, several improvements were made for the extensive trial. These improvements include the visual appearance of VBA media, where also the display is designed to be more realistic and more ethnomathematics. Also, changes in appearance were made because they adjusted to the students' level of thinking, which was still very real. Result of a revision made and given in the comprehensive trial. There are changes to the device and media (see Figure 3).

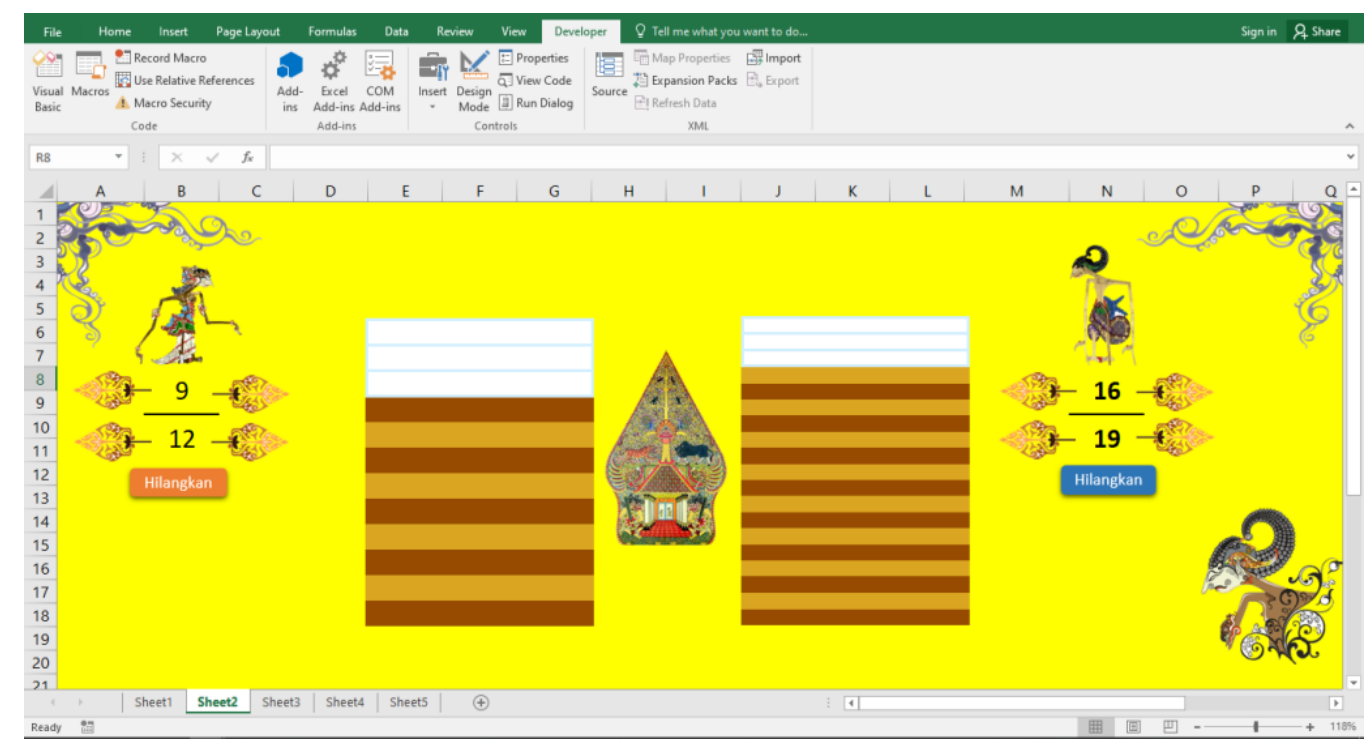

Figure 3. Example of media in comprehensive trial and product trial

After the comprehensive trial was carried out, the validation test was conducted, based on the validation results, no revisions had to be made so that it could be continued to the product test. Product testing is carried out by comparing learning and comparing the results of students' mathematical reasoning abilities between those using interactive learning models and those using ordinary learning. 


\subsubsection{The validation of interactive learning model using VBA for microsoft excel with ethnomatematical contents}

Validation of this interactive learning model consists of logical validation by two learning expert lecturers and one IT expert lecturer, user validation by three experienced teachers, and audience validation in the form of student responses obtained from the results of distributing questionnaires.

Logical validation and user validation in the form of an assessment of the components of the learning model which includes 1) Syntax (Learning model steps), 2) Social Systems (Teacher and student communication patterns), 3) Reaction Principles (Teacher and student responses), 4) Support (Learning Media with VBA and Ethnomatematic Use), and 5) Instructional Impact (Achievement of desired student abilities). Meanwhile, audience validation contains indicators of student responses to teacher material and activities from the beginning to the end of the lesson. The results of logical (expert) validation, user and audience validation of the VBA for Microsoft Excel assisted interactive learning model with Ethnomatematical contents are simplified in Table 2.

Table 2. Validation result

\begin{tabular}{cccc}
\hline Validation Elements & Average Score & Percentage (\%) & Criteria \\
\hline Logical Expert & 21.33 & 88.89 & Very Valid \\
User & 20.66 & 86.11 & Very Valid \\
Audience & 20.64 & 86.00 & Very Valid \\
\hline Average & 20.88 & 87.00 & Very Valid \\
\hline
\end{tabular}

Table 2 show that the three validators scores are in very valid criteria, according to Akbar (2013), it can be concluded that the learning model is in very valid criteria. So the interactive learning model can be used in product testing without having to revise it again.

\subsubsection{Teachers and students' responses to learning interactive models}

In limited trials and more extensive trials, researchers conducted interviews with six teachers in primary schools which were the research sites and distributed questionnaires to students in 6 elementary schools to find out the responses of teachers and students to the developed interactive learning model. The results of interviews with the teachers that reflect the teacher's responses are described in Table 3.

Table 3. Teachers'responses

\begin{tabular}{crcl}
\hline No & Activity & Teachers' Code & \multicolumn{1}{c}{ Responses } \\
\hline 1. & Limited Trials & G1 & $\begin{array}{l}\text { Interactive learning is quite exciting } \\
\text { and has a relationship with a concept } \\
\text { that is well known to students, namely } \\
\end{array}$ \\
& & culture. \\
\hline
\end{tabular}

2. Extensive Trials G2

This alternative learning should also be made of physical media on the same material, but you do not have to use a laptop because many students are not used to using laptops in learning. 


\begin{tabular}{|c|c|c|c|}
\hline No & Activity & Teachers' Code & Responses \\
\hline & & $\mathrm{G} 3$ & $\begin{array}{l}\text { Learning with an interactive model } \\
\text { that was developed makes learning } \\
\text { more interactive than usual for } \\
\text { children to be more excited }\end{array}$ \\
\hline & & G4 & $\begin{array}{l}\text { Through this learning, students } \\
\text { generally become more motivated to } \\
\text { learn fractions and with the media in } \\
\text { this learning students are enthusiastic } \\
\text { about trying the existing media } \\
\text { themselves. }\end{array}$ \\
\hline & & G5 & $\begin{array}{l}\text { Learning with this ICT-based } \\
\text { interactive learning model is very } \\
\text { good, exciting and more comfortable } \\
\text { to convey material to students, } \\
\text { students are more enthusiastic about } \\
\text { learning, students also understand the } \\
\text { material being taught faster. }\end{array}$ \\
\hline & Product testing & G6 & $\begin{array}{l}\text { This interactive learning model is a } \\
\text { breakthrough learning model that } \\
\text { combines interactive mathematics } \\
\text { learning, culture (ethnomathematics) } \\
\text { and technology. Media is beneficial in } \\
\text { teaching students the concept of } \\
\text { fractions and practising their } \\
\text { reasoning skills. }\end{array}$ \\
\hline
\end{tabular}

Table 3 show that the almost all teachers gave positive responses. The learning model is quite exciting and can help teachers to motivate their students to learn mathematics. Based on students' responses from the results of distributing questionnaires, it was found that the average student responded with an average of $90.25 \%$ of the total score. These results indicate that the student's response is quite positive to this interactive learning model.

\subsubsection{Students' mathematical reasoning abilities in product testing}

Students are given a reasoning ability test when testing products and the results are compared with students who use ordinary learning. Following are the results of inferential statistical data processing. Results of the normality test between the pretest and posttest on students' mathematical reasoning abilities (see Table 4).

Table 4. Result of the normality test

\begin{tabular}{cccc}
\hline & \multicolumn{3}{c}{ Kolmogorov-Smirnov } \\
\cline { 2 - 4 } & Statistic & df & Sig. \\
\cline { 2 - 4 } Pretes & 0.197 & 36 & 0.001 \\
Postes & 0.193 & 36 & 0.002 \\
\hline
\end{tabular}


Table 4 show that the pretest and posttest have a significance $<0.05$, so it can be concluded that the data are not normally distributed. Thus the further data processing is to use the non-parametric test for two independent samples special Mann Whitney $U$ with Monte Carlo (see Table 5).

Table 5. The result of the non-parametric test

\begin{tabular}{llll}
\hline Mann-Whitney U & & 0.000 \\
\hline Monte Carlo Sig. (1-tailed) & Sig. & 0.000 \\
\cline { 2 - 4 } & $\begin{array}{l}95 \% \\
\text { Confidence } \\
\text { Interval }\end{array}$ & $\begin{array}{l}\text { Lower } \\
\text { Bound }\end{array}$ & 0.000 \\
\cline { 3 - 4 } & & Upper Bound & 0.000 \\
\hline
\end{tabular}

Based on the inferential statistical test results in Table 5, a significance value of $<0.05$ means that Ho is rejected. It means that the achievement of students' mathematical reasoning abilities after being given learning with interactive models using VBA for Microsoft Excell with ethnomathematics content is better than mathematical reasoning ability which using ordinary learning.

\subsection{Discussion}

The overall stages of developing an interactive learning model with VBA for Microsoft Excel with ethnomathematic content in principle consist of two important steps, namely 1) Developing a product consisting of preliminary study stages, FGD, limited trials, wider trials, product testing and socialization; 2) Validating done by experts, users and student responses. These steps are in line with the opinion of Borg \& Gall (1989). They say that educational development research $(\mathrm{R} \& \mathrm{D})$ is a process used to develop and validate educational products. The results of development research are not only for developing existing products but also for finding knowledge or answers to practical problems. Based on the research procedures carried out, it can be concluded that the stages carried out in research fulfill the steps of a development research.

The three scores given by the validator, the results are in very valid criteria (based on the criteria given by Akbar (2013), so it can be concluded that the learning model is in very valid criteria. Based on the results of these averages, the interactive learning model can be used in product testing without having to do the revision stage again. The effectiveness of learning with this interactive model is in line with several researchers (Mutiarni, 2016; Rohaeti et al., 2019; Maharani, 2015; Sukarmin et al., 2018).

Based on the results obtained, it can be denied that this learning model is quite interesting and can help teachers in motivating their students to learn mathematics. The results obtained indicate that the student response is quite positive to this learning. The results of this study can increase students' interest in learning mathematics, thus learning mathematics becomes more enjoyable in the eyes of students, such as research conducted several researchers (Irawan \& Suryo, 2017; Priyambodo et al., 2012).

The achievement of students' mathematical reasoning abilities after being given learning with interactive models using VBA for Microsoft Excell with ethnomathematics content is better than mathematical reasoning ability which using ordinary learning. It happens because learning using an interactive model using VBA for Microsoft Excell with ethnomathematics content leads students to be able to draw messages from a series of concepts that are constructed. Hence, students become better as conveyed by Kadarisma 
(2019), first fill in contextual ethnomathematics content so that it makes students more interested, motivated and more comfortable to imagine the media which makes the results of students' mathematical reasoning better (Costu et al., 2009; Gainsburg, 2008). The results of this study are also in line with research that has been conducted by several previous researchers (Amir et al., 2018; Aprisal \& Abadi, 2018; Mulyana \& Sumarmo, 2015; Nunes et al., 2007; Saleh et al., 2018).

\section{CONCLUSION}

Based on the analysis of the research results, it can be concluded that the development of VBA-assisted and ethnomatematically-loaded interactive learning models go through two major stages, namely product development and validation. Based on the results of the validation of the three validator elements, the learning model developed is included in the very valid criteria. Furthermore, teachers and students' responses were generally positive. Beside that the students' mathematical reasoning abilities using interactive learning models are better than those using ordinary learning.

\section{ACKNOWLEDGEMENTS}

Thank you to the Ministry of Research, Technology and Higher Education who fund the research. Board of Rectors of Siliwangi Teacher Training and Education Institute (IKIP Siliwangi) who have provided support in research activities. Leaders and teachers at one of Sate Primary School in Cimahi who have facilitated the implementation of the research.

\section{REFERENCES}

Akbar, S. (2013). Instrumen Perangkat Pembelajaran, Bandung. PT Remaja Rosda Karya.

Amir, M. F., Hasanah, F. N., \& Musthofa, H. (2018). Interactive multimedia based mathematics problem solving to develop students' reasoning. International Journal of Engineering and Technology(UAE), 7(2.14), 272-276.

Aprisal, A., \& Abadi, A. M. (2018). Improving students' mathematical reasoning and selfefficacy through Missouri mathematics project and problem-solving. Beta: Jurnal Tadris Matematika, 11(2), 191-207. https://doi.org/10.20414/betajtm.v11i2.206

Barton, B. (1996). Making sense of ethnomathematics: ethnomathematics is making sense. Educational Studies in Mathematics, 31, 201-233. https://doi.org/10.1007/BF00143932

Bernard, M. (2014). Meningkatkan Kemampuan Penalaran Matemattik Siswa Sma Melalui Game Adobe Flash CS 4. Prosiding Seminar Nasional Pendidikan Matematika STKIP Siliwangi, 2, 205-213.

Bernard, M. (2015). Meningkatkan Kemampuan Komunikasi dan Penalaran serta Disposisi Matematik Siswa SMK dengan Pendekatan Kontekstual melalui Game Adobe Flash cs 4.0. Infinity, 4(2), 197-222. https://doi.org/10.22460/infinity.v4i2.p197-222

Borg, W. R., \& Gall, M. (1989). Education Research: An Introduction (4th Edition). New York: Longman publisher.

Chotimah, S., Bernard, M., \& Wulandari, S. M. (2018). Contextual approach using VBA learning media to improve students' mathematical displacement and disposition ability. Journal of Physics: Conf. Series, 948(1), 012025. 
https://doi.org/10.1088/1742-6596/948/1/012025

Costu, S., Arslan, S., Çatlıo, H., \& Birgin, O. (2009). Perspectives of elementary school teachers and their students about relating and contextualizing in mathematics. Procedia Social and Behavioral Sciences, 1, 1692-1696. https://doi.org/10.1016/j.sbspro.2009.01.300

d'Ambrósio, U. (2006). Ethnomathematics: Link between traditions and modernity. BRILL.

Fitriani, N., Suryadi, D., \& Darhim, D. (2018). The Students' Mathematical Abstraction Ability Through Realistic Mathematics Education With Vba-Microsoft Excel. Infinity, 7(2), 123-132. https://doi.org/10.22460/infinity.v7i2.p123-132

Gainsburg, J. (2008). Real-world connections in secondary mathematics teaching. Journal of Mathematics Teacher Education, 11(3), 199-219. https://doi.org/10.1007/s10857007-9070-8

Irawan, E., \& Suryo, T. (2017). Implikasi Multimedia Interaktif Berbasis Flash Terhadap Motivasi dan Prestasi Belajar Matematika. Beta Jurnal Tadris Matematika, 10(1), 33. https://doi.org/10.20414/betajtm.v10i1.17

Joyce, B., \& Weil, M. (1986). Models of teaching. Engle-wood Cliffs. New Jersey.

Kadarisma, G., Nurjaman, A., Sari, I. P., \& Amelia, R. (2019). Gender and mathematical reasoning ability. Journal of Physics: Conference Series, 1157(4), 042109. https://doi.org/10.1088/1742-6596/1157/4/042109

Mullis, I. V. S., Martin, M. O., Foy, P., \& Hooper, M. (2015). TIMSS 2015 International Results in Mathematics. IEA.

Mulyana, A., \& Sumarmo, U. (2015). Meningkatkan Kemampuan Penalaran Matematik dan Kemandirian Belajar Siswa SMP melalui Pembelajaran Berbasis Masalah. Didaktik, 9(1), 40-51.

Mutiarni, R. (2016). Efektivitas Pembelajaran Micrososft Excel Berbasis Interaktif Pada Mata Kuliah Teknologi Informasi Dan Komunikasi (Tik) (Study Kasus Pada Mahasiswa Manajemen STIE PGRI Dewantara Jombang). Eksis: Jurnal Riset Ekonomi Dan Bisnis, 11(2). https://doi.org/10.26533/eksis.v11i2.46

Nugraha, Y., Akbar, P., \& Bernard, M. (2015). Pengaruh Kemandirian Belajar Siswa SMP terhadap Kemampuan Penalaran Matematis. Journal On Education, 1(2), 288-296.

Nunes, T., Bryant, P., Evans, D., Bell, D., Gardner, S., Gardner, A., \& Carraher, J. (2007). The contribution of logical reasoning to the learning of mathematics in primary school. British Journal of Developmental Psychology, 25(1), 147-166. https://doi.org/10.1348/026151006X153127

Nurkhaeriyyah, T. S., Rohaeti, E. E., \& Yuliani, A. (2018). Analisis kemampuan penalaran matematis siswa mts di kabupaten cianjur pada materi teorema pythagoras. JPMI (Jurnal Pembelajaran Matematika Inovatif), 1(5), 827-836. https://doi.org/10.22460/jpmi.v1i5.p827-836

Priyambodo, E., Wiyarsi, A., \& Sari, R. L. P. (2012). Pengaruh Media Pembelajaran Interaktif Berbasis Web Terhadap Motivasi Belajar Mahasiswa. Jurnal Kependidikan, 42(2), 99-109. https://doi.org/10.21831/jk.v42i2.2236

Rohaeti, E. E., Bernard, M., \& Primandhika, R. B. (2019). Developing Interactive Learning Media For School Level Mathematics Through Open-Ended Approach Aided By 
Visual Basic Application For Excel. Journal on Mathematics Education, 10(1), 5968. https://doi.org/10.22342/jme.10.1.5391.59-68

Saleh, M., Prahmana, R. C. I., Isa, M., \& Murni. (2018). Improving the reasoning ability of elementary school student through the Indonesian realistic mathematics education. Journal on Mathematics Education, 9(1), 41-53. https://doi.org/10.22342/jme.9.1.5049.41-54

Maharani, Y. (2015). Efektivitas Multimedia Pembelajaran Interaktif Berbasis Kurikulum 2013. Indonesian Journal of Curriculum and Educational Technology Studies, 3(1), 31-40.

Sukarmin, S., Poedjiastoeti, S., Novita, D., \& Lutfi, A. (2018). Effectivity of Interactive Multimedia and Student Activity Sheets with Writing-To-Learn (WTL) Strategy in Science Learning for Hearing Impairment Students. National Seminar on Chemistry (SNK 2018), 211-217. https://doi.org/10.2991/snk-18.2018.47 
